\title{
In Memoriam \\ ROBERT D. CUFF, 1941-2001
}

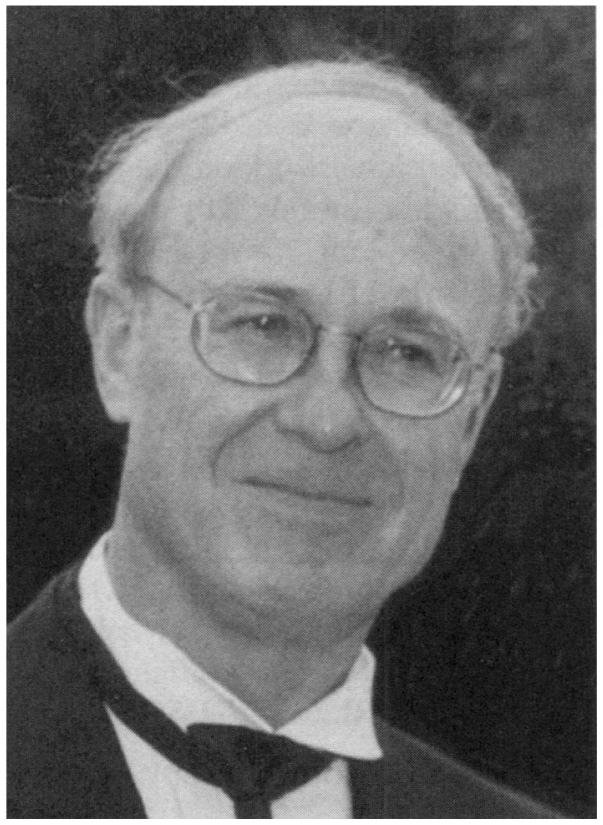

The Business History Review mourns the death of Robert D. Cuff, for many years a professor of history and policy at York University in Ontario, with appointments in both the Faculty of Arts and the Schulich School of Business.

Bob Cuff was twice a member of our editorial board (from 1971 to 1974 and 1983 to 1986) and a frequent contributor. Over the years, he wrote five articles and seventeen book reviews for our journal. To mark his passing, we publish the comments made at his funeral in November 2001 by longtime friends Neville Thompson of the University of Western Ontario and Thomas K. McCraw of the Harvard Business School.

We also include a complete list of his books and articles, and a short paper that Bob himself delivered at Harvard in October of 2000, as part of a panel entitled "Bringing the Entrepreneur Back into Busi-

Business History Review 76 (Spring 2002): 111-122. (C) 2002 by The President and Fellows of Harvard College. 
ness History." His remarks focus on Harvard's Research Center in Entrepreneurial History, an organization founded in 1948. A number of remarkable economists and historians did pioneering work at the Center. They included Joseph A. Schumpeter, Bernard Bailyn, Alfred D. Chandler Jr., Thomas C. Cochran, Arthur H. Cole, Leland H. Jenks, and David S. Landes. The paper discusses why so many members of the Center, which lasted for ten years, eventually turned their focus toward organizations rather than individuals.

After he had given his talk, we asked Bob to develop it into an article, and he had begun additional work on the piece shortly before his death. He was a perfectionist, and this is by no means the finished version that would have satisfied him. We present it as a work-in-progress that typifies his approach to historical problems and his unswerving emphasis on primary research.

-The Editors

\section{Neville Thompson}

\section{Professor of History, University of Western Ontario}

Вов CUFF was one of my oldest and best friends. I first met him in September 1963 , on what must certainly have been a sunny day, as all the days of our glad, confident youth were, and last saw him on another beautiful September day of this year, when we went to a performance at Stratford of Henry IV, Part II, sometimes billed as Falstaff, now alas memorable in more ways than I would like. In between were thirtyeight years of close and cloudless friendship.

On the first occasion, we were graduate students at Princeton University, rightly described by F. Scott Fitzgerald as being just "this side of paradise," an institution that we probably only dimly appreciated before we arrived as being synonymous with wealth and style as well as learning. Innocents abroad, Canadians in the history program and living across the quadrangle from each other in the graduate college, we had a lot in common. It was easy to be awed by the architecture, which was an improved version of Oxford Gothic, by dinner in the hall in gowns, and by the reputation of the faculty, whom we had previously known only as names on spines of books. Fortunately, we were pro- 
tected as much by naiveté as sophistication, and we affected, at least, not to be overly impressed.

This was still recognizably the university of Woodrow Wilson, which he had left half a century earlier to apply the remodeling skills he had honed as its president, first to the United States, and then to Europe after the First World War. His papers were being edited and published by a legendarily efficient academic who sat at Wilson's desk. Thus, it took great courage to march into the shrine and claim a major topic connected with Wilson. Bob was not a Falstaff, brawling and shouting his way through life, but a person of modesty, discretion, and temperate judgment. But he did not lack confidence. Rather than picking some small, well-circumscribed subject on which he would remain forever the unchallenged expert, he seized on the huge issue of American mobilization for the First World War: war, business, the economy, society, and technology were the elements that he combined. All the research and writing was completed in about a year, making him one of only two historians I have ever known to accomplish such a feat. And what a thesis it was! The book that resulted from it, The War Industries Board: Business-Government Relations during World War I (1973), is probably still the first, if not the last, word on the subject, and it formed the basis for his further research, publications, and teaching on business and government relations in the United States and Canada. It was a tribute to this early achievement that as soon as he finished his thesis he was appointed to the faculty at Princeton. There, however, only the senior faculty propounded their version of the truth in lectures. Assistant professors, almost literally assistants to the professors, directed the preceptorials, which was the local term for tutorials. Bob yearned to do real teaching, and after a year and a half he left for the University of Rochester, where he was welcome to do as much of any kind of instructing as he liked. He never thereafter ceased to be puzzled by this youthful decision and by the romantic conception he held about lecturing in those early days.

But for many of us who were graduate students with Bob, the most memorable event was the arrival, on another fine day, of Mary Lou on her first visit. Even if she had found herself in better circumstances than a secular monastery overstocked with testosterone, Mary Lou would have been a great favorite with the wonks, as she was with everyone else. She and Bob are inseparable in the minds of us all, and in celebrating his life and achievement we also commemorate hers. If he had not married Mary Lou at the end of his first year in graduate school, Bob may well not have completed his thesis in a year. With her cheerful disposition and practicality, from which many others also benefited, she countered the endemic gloomy, scholarly introspection and put in 
perspective the anxieties and footling concerns of academic life that loom so large to those immersed in them, but seem so trivial in the larger scheme of things.

After spending a couple of years at Rochester, Bob transferred to York University in Toronto in 1969. Although he spent over thirty years on the faculty there, Bob was often a visiting scholar at leading American institutions: appropriately at the Woodrow Wilson Center in Washington, Johns Hopkins University, and, most often, at Harvard, both in the History Department and, more frequently, in the Business School. Over several years, the family became part of the community of Lexington, Massachusetts, where the shot heard around the world was fired at the beginning of the American Revolution. Apart from visits, we also kept in touch by letter and telephone, and in the last few years by e-mail.

In addition to his wise and sensible judgment, Bob had a marvelous sense of irony and detachment and a fine appreciation for the human condition in both its nobility and its folly. His letters and conversation were full of comments on situations, institutions, and individuals that were always wry, occasionally verged on the disrespectful, and might sometimes even have been seen by those of particularly sensitive and injured dispositions as libelous. How we shall all miss his reflections on the kaleidoscope of life and literature. How much our lives and our world are diminished by the absence of him and Mary Lou. But how lucky we were to be touched by them. They are assured of earthly immortality in their children and grandchildren, and in the hearts and minds of all of us here today and many others. "But O for the touch of a vanish'd hand/ And the sound of a voice that is still!"

\section{Thomas K. McCraw}

Isidor Straus Professor of Business History

Harvard Business School

IT IS A PRIVILEGE to speak about Bob, and I thank his children for the honor of asking me. He was one of the best all-around persons I've ever known. There's actually some hard evidence for this "best all-around" label, and I'll get to that in a minute. But first I want to talk briefly about two other things: his work as a scholar and teacher; and his 
thirty-five-year marriage to Mary Lou, who as you know died just two years ago after a heroic struggle with her own illness.

\section{The Scholar and Teacher}

Bob was what is known in our profession as "productive." As his long list of publications shows, he wrote or coauthored several books, scores of articles, and more than a hundred book reviews, some of which were still in press at the time of his death.

He was one of the world's great students of industrial mobilization for war, and for many aspects of that subject, the leading authority. Mobilization is a big, messy, and immensely complex topic. To study it well requires not only a broad knowledge of business-government relations, but also a detailed understanding of particular industries, and above all a deep and nuanced appreciation of the way in which organizations work: big, small, and medium-sized organizations. To do the topic justice requires a multidisciplinary approach, and Bob never shrank from that task. He steeped himself in the literatures of history, political science, sociology, and business administration, and he was one of the best-read scholars I've ever known. He kept up with these literatures, as evidenced not only by the immense reach of his knowledge but also by the remarkable number and range of books he reviewed.

I think the jewels of Bob's scholarly output were the articles he wrote about U.S. war mobilization during the twentieth century, a topic that made him better known as a scholar in the United States than in his native Canada. Bob researched these articles in all the archives and private papers known to be pertinent and in many that he uncovered himself. He was obsessed with getting as much evidence from primary sources as possible. He sought out relevant material the way bloodhounds follow a scent, and the results infused his work with genuine historiographical mastery. As my colleague Richard Tedlow said to me the other day, Bob's articles on mobilization are so authoritative that people will be reading them a hundred years from now.

As a teacher, Bob was respected and beloved by the hordes of students he taught. He did everything an outstanding teacher is supposed to do. He believed teaching to be a calling, a sort of sacred vocation. He always knew his audience, and he had a sure sense of the appropriate pitch. He wrote superb lectures. He ran great seminars. He demanded students' best efforts. He listened. Most of all, he cared.

\section{Mary Lou and the Children}

We all know many married couples, but we know a small number who are so wrapped up in each other that it's impossible to think of the one without thinking of the other. Bob and Mary Lou epitomized this 
rare kind of relationship. They had a true love match, which, despite their premature deaths, lasted for forty years. They were high-school sweethearts in Peterborough, Ontario, then classmates at the University of Toronto, and spouses for thirty-five years. The last five of those years were sometimes unspeakably tough for them because of Mary Lou's illness. But part of the glory of their marriage was the way the two of them lived these years, endured them, and set an example nobody who knew them can ever forget.

Kierkegaard once wrote that to the extent any life can be understood it is only in retrospect; but that it has to be lived in prospect, going forward into an uncertain future. So let us look at this partnership prospectively, as it was lived: not backward from 2001 but forward from 1964, the date of their wedding. Ask yourself whether at that time, looking ahead with foreknowledge, they would have been satisfied with the thirty-five years of marriage they were about to begin. Would they have settled for the career Bob had as a university teacher and a worldrenowned scholar? For Mary Lou's rich and multifaceted life as a mother, a high-school math teacher, and the cheeriest of human beings - one of those people who make everyone around them a little bit happier all the time? And, most important, for the three wonderful children they gave to the world-Christine, Peter, and Kateaccomplished, devoted, terrific children?

Surely the answer is yes. What sane person wouldn't settle for all of that?

So, on the one hand, we're mourning two lives cut tragically short. Looking backward, we know that neither Mary Lou nor Bob reached the Biblical three score and ten that we all sort of feel entitled to. But looking forward from the 1960 s, we confront a pair of lives that were going to be spent together for the better part of forty years. Who among us wouldn't be overjoyed to contemplate a life together that was destined to be so rich, so full, so productive, so loving? Because what we're really talking about is a glorious love story, whose end we now have to mourn but that we really should be celebrating. We should congratulate Mary Lou and Bob for the lives they lived, and I do that now for all of us.

\section{Best All-Around}

Finally we come to the man himself, Robert Dennis Cuff. I met him in 1973 when we were postdoctoral fellows at Harvard, he at the History Department's Warren Center, I at the Business School. Everybody who knew him quickly discovered several things that defined him as a person. One was that in any conversation nothing was ever about him. It was about you, or your work, or your family, or his family. Bob was a 
very private person, as many academics are, and we've all known a lot of private people. Most of us have also known a fair number of people who seem to have a special gift for making friends, and Bob was one of those as well. But we've known only a tiny number who had both these traits: a great aptitude for making friends combined with a sort of fierce privacy.

At the end of our postdoctoral year at Harvard, we attended a small going-away party. In the way of such gatherings, the wine flowed and the conversation began to drift into random subjects, such as the experience of going to high school. I remember at one point blurting out to the group, "I bet Bob was voted best all-around in his class." (This wasn't a very tactful thing to say. What if he hadn't been?) Mary Lou confirmed that he actually had been so voted, a fact that Bob quickly deflected by saying, "But Mary Lou was elected a cheerleader!"

Among many common interests Bob and I had, we were both World War II junkies. A few months ago, we started a plan to coauthor a series of articles about industrial mobilization in different U.S. industries during the $1940 \mathrm{~s}$. We were going to produce a large but conveniently unspecified number of self-contained pieces that we'd complete as we progressed beyond the age of sixty. This project would help to carry us into retirement and much beyond, until we gracefully faded away. Somehow or other a lot of the work was going to get done on the golf course. But that wasn't going to adulterate it in the slightest. Rather it was going to give us a unique perspective that would lend exemplary merit to our final legacies as scholars. This was no castles-inair plan, and one of the deepest pains I feel in his death is that the sheer pleasure of this joint work is not going to materialize.

As everyone with even a casual acquaintance with Bob knows, he never tooted his own horn. He was the most modest, decent, and charitable of men. To my knowledge, he was not particularly religious, and neither am I. But there's no better illustration of his essence than the oft-quoted passage St. Paul wrote about charity in one of his letters to the Corinthians: Charity "vaunteth not itself, is not puffed up, doth not behave itself unseemly, seeketh not her own, is not easily provoked, thinketh no evil, rejoiceth not in iniquity, but rejoiceth in the truth." That was Bob Cuff.

In thinking about the meaning of his life, I ask your indulgence in quoting St. Paul one more time, this from a letter to the Philippians: "Finally, brethren, whatsoever things are true, whatsoever things are honest, whatsoever things are just, whatsoever things are pure, whatsoever things are lovely, whatsoever things are of good report; if there be any virtue, and if there be any praise, think on these things." On behalf of everyone who knew him, I thank Bob for leaving us so many of these things to think on. Best all-around. 


\title{
Robert D. Cuff's Publications
}

\begin{abstract}
BOOKS
Coeditor and contributor. War and Society in North America. Toronto: Thomas Nelson and Sons, 1971.

Author. The War Industries Board: Business-Government Relations during World War I. Baltimore: Johns Hopkins Press, 1973.

Coeditor. Enterprise and National Development: Essays in Canadian Business and Economic History. Toronto: Hakkert Press, 1973.

Coauthor. Canadian-American Relations in Wartime: From the Great War to the Cold War. Toronto: Hakkert Press, 1974.

Coauthor. Ties That Bind: Canadian-American Relations in Wartime from the Great War to the Cold War. Toronto: Hakkert Press, 1977 (second edition of Canadian-American Relations in Wartime).

Coauthor. American Dollars/Canadian Prosperity: Canadian-American Economic Relations, 1945-1950. Toronto: Hakkert Press, 1978.

Coeditor. An American History Reader. Toronto: Canadian Scholar's Press, 1988.
\end{abstract}

\section{ARTICLES}

"The Conservative Party Machine and the Election of 1911 in Ontario." Ontario History 57 (September 1965): 149-56. Reprinted in The 1911 General Election: A Study in Canadian Politics, edited by Paul Stevens, 205-10. Toronto: Copp Clark Pittman, 1970.

"The Toronto Eighteen and the Election of 1911." Ontario History 57 (December 1965): 169-80.

"A Dollar-A-Year Man in Government: George N. Peek and the War Industries Board." Business History Review 41 (Winter 1967): 404-20.

"The Dollar-A-Year Men of the Great War." Princeton University Library Chronicle 30 (Autumn 1968): 10-24.

"Bernard Baruch: Symbol and Myth in Industrial Mobilization." Business History Review 43 (Summer 1969): 115-33. Reprinted in Men and Organizations: The American Economy in the Twentieth Century, edited by Edwin J. Perkins. New York: Putnam, 1977.

"Woodrow Wilson and Business-Government Relations during World War I." Review of Politics 31 (July 1969): 385-407.

"Woodrow Wilson's Missionary to American Business, 1914-1915: A Note." Business History Review 43 (Winter 1969): 545-51.

"Organizing for War: Canada and the United States during World War I." In Canadian Historical Association, Historical Papers, 1969, 141-56. 
“The University and Values." Rochester Review (Winter 1969): 20-1.

"Newton D. Baker, Frank A. Scott, and 'The American Reinforcement in the World War." Military Affairs 34 (February 1970): 11-13.

With Melvin I. Urofsky. "The Steel Industry and Price-Fixing during World War I.” Business History Review 44 (Autumn 1970): 291-306. Reprinted in Interpreting Twentieth Century America: A Reader, edited by Joseph F. Wall and Richard Lowitt, 113-25. New York: Thomas Y. Crowell, 1973.

“Samuel Gompers, Leonard Wood and Military Preparedness: A Note." Labor History 12 (Spring 1971): 280-8.

"Business, the State, and World War I: The American Experience." In War and Society in North America, edited by J. L. Granatstein and R. D. Cuff, 1-19. Toronto: T. Nelson, 1971. Reprinted in The Ordeal of Twentieth-Century America: Interpretive Readings, edited by Jordan A. Schwarz, 49-63. Boston: Houghton Mifflin, 1974.

"An American Progressive Looks North: A Note." Canadian Review of American Studies 3 (Spring 1972): 45-9.

"The Cooperative Impulse and War: The Origins of the Council of National Defense and Advisory Commission." In Building the Organizational Society, edited by Jerry Israel, 233-46. New York: Free Press, 1972.

With J. L. Granatstein. "Canada and the Perils of 'Exemptionalism." Queen's Quarterly 79 (Winter 1972): 473-81.

With J. L. Granatstein. "Looking Back at the Cold War: 1945-54." Canadian Forum (July/August 1972): 8-11. Reprinted in Partners Nevertheless: Canadian-American Relations in the Twentieth Century, edited by Norman Hillmer, 206-13. Toronto: Copp Clark, 1989.

"American Historians and the 'Organizational Factor." Canadian Review of American Studies 4 (Spring 1973): 19-31.

With J. L. Granatstein. "The Hyde Park Agreement of 1941." Canadian Historical Review 45 (Spring 1974): 59-80.

"We Band of Brothers: Woodrow Wilson's War Managers." Canadian Review of American Studies 5 (Fall 1974): 135-48.

“The Wilsonian Mobilization: An Interpretation." Tamkang Journal (November 1975): 90-105.

"The Historian As Pessimist." Canadian Review of American Studies 79 (Spring 1976): 95-101 (on historian Robert Wiebe).

"Herbert Hoover: The Ideology of Voluntarism and War Organization during the Great War." Journal of American History 64 (September 1977): 358-72. Reprinted in Herbert Hoover, the Great War and Its Aftermath, edited by Lawrence Gelfand, 23-39. Ames: University of Iowa Press, 1979.

With J. L. Granatstein. "The Rise and Fall of the Free Trade Idea, 1947-49." Canadian Historical Review 58 (December 1977): 458-82.

With J. L. Granatstein. "Canada and the Marshall Plan, June-December 1947." In Canadian Historical Association, Historical Papers, 1977, 197-213. 
"Wilson and Weber: Bourgeois Critics in an Organized Age." Public Administration Review 38 (May-June, 1978): 240-4.

"An Organizational Perspective on the Military-Industrial Complex." Business History Review 52 (Summer 1978): 250-67. Reprinted in GovernmentBusiness Cooperation, 1945-1964: Corporatism in the Post-war Era, edited by Robert F. Himmelberg. New York: Garland, 1994.

"Harry Garfield, the Fuel Administration and the Search for a Co-operative Order during World War I.” American Quarterly 30 (Spring 1978): 39-53. Reprinted in Government-Business Cooperation, 1945-1964: Corporatism in the Post-war Era, edited by Robert F. Himmelberg. New York: Garland, 1994.

"From Market to Manager." Canadian Review of American Studies 10 (Spring 1979): 47-54 (on historian Alfred D. Chandler Jr.).

"Herbert Hoover and the Pork Packing Agreement of 1917-1919: The Dilemmas of Voluntarism." Agricultural History (October 1979): 727-47.

"Veblen and Toronto." Canadian Review of American Studies 10 (Winter 1979): 347-53.

"The Politics of Labor Administration during World War I." Labor History 21 (Fall 1980): 546-59.

"Bernard Baruch." In Dictionary of American Biography, Supplement Seven: 1961-1965, 34-7. New York: Scribner, 1981.

"Antitrust Adjourned: Mobilization and the Rise of the National Security State." In Federal Trade Commission, Bureau of Competition, National Competition Policy: Historians' Perspectives on Antitrust and Government-Business Relationships in the United States, ch. 5. Washington, D.C.: U.S. Department of Commerce, 1981.

"American Mobilization for War, 1917-1945." In Mobilization for Total War: The Canadian, American and British Experience, 1914-1918, 1939-1945, edited by N. F. Dreisziger, 73-86. Waterloo, Ont.: Wilfrid Laurier University Press, 1981.

"Harry Garfield." In Biographical Dictionary of Internationalists, edited by Warren F. Kuehl, 280-1. Westport, Conn.: Greenwood Press, 1983.

"Commentary: Economic Mobilization in World War II." Proceedings of the Tenth Military History Symposium, The Home Front and War in the Twentieth Century, 111-18. Colorado Springs: U.S. Air Force Academy, 1984. Reprinted in Survival of Corporatism in the New Deal Era, 1933-1945, edited by Robert F. Himmelberg. New York: Garland, 1994.

"Ferdinand Eberstadt, the National Resources Board, and the Search for Integrated Mobilization Planning, 1947-1948." The Public Historian (Fall 1985): 37-52. Reprinted in Government-Business Cooperation, 1945-1964: Corporatism in the Post-war Era, edited by Robert F. Himmelberg. New York: Garland, 1994.

"From the Controlled Materials Plan to the Defense Materials System, 19421953." Military Affairs 51 (January 1987): 1-6.

"Stockpiles and Defense Escalation, 1965-1968." The Public Historian 9 (Fall 1987): 45-64. 
"Mobilization and Railroad Transportation: Lessons in Coordination and Control, 1917-1945." Military Affairs 53 (January 1989): 33-50. Reprinted in Business-Government Cooperation, 1917-1932: The Rise of Corporatist Policies, edited by Robert F. Himmelberg. New York: Garland, 1994.

"Ernest Poole: Novelist as Propagandist, 1917-1918: A Note." Canadian Review of American Studies 19 (Summer 1989): 183-94.

"Private Success, Public Problems: The Du Pont Corporation and World War I." Canadian Review of American Studies 20 (Fall 1989): 173-89.

"Creating Control Systems: Edwin F. Gay and the Central Bureau of Planning and Statistics, 1917-1919." Business History Review 63 (Autumn 1989): 588613.

"Organizational Capabilities and U.S. War Production: The Controlled Materials Plan of World War II." Business and Economic History, 2nd series, 19 (1990): 103-12.

"War Mobilization, Social Learning, and State Building: 1917-1941." In The State and Social Investigation in Britain and the United States, edited by Michael J. Lacey and Mary Furner, 388-425. New York: Cambridge University Press, 1993.

“Organizing U.S. Aircraft Production for War, 1938-1944: An Experiment in Group Enterprise." In Proceedings of the Twentieth Fuji Conference, 106-128. Tokyo: University of Tokyo Press, 1994.

"Arch W. Shaw, the Harvard Business School, and An Approach to Business Problems." Business History, Proceedings of the Administrative Sciences Association of Canada, 16 (1995): 43-52.

"Edwin F. Gay, Arch W. Shaw, and the Uses of History in Graduate Education for Managers." Journal of Management History 2 (1996): 9-25.

"Strengthening Proprietary Capitalism in a Corporate Age: The Case of Arch W. Shaw." Business History, Proceedings of the Administrative Sciences Association of Canada 18 (1997): 35-43.

“Harry A. Garfield." In American National Biography, vol. 8, edited by John A. Garraty and Mark Carnes, 713-15. New York: Oxford University Press, 1999.

"Edward N. Hurley." In American National Biography, vol. 11, edited by John A. Garraty and Mark Carnes, 561-3. New York: Oxford University Press, 1999.

“The National War Labor Board (WWI)." In Dictionary of American History (forthcoming).

"Why Was General Motors a Success? A Note." Journal of Management History (forthcoming).

\section{CASES}

“Canada under New Management: 1984." Harvard Business School Case Services, 1986, \#9-386-159.

"Organizational Capabilities and U.S. War Production: The Controlled Materials Plan of World War II." Harvard Business School Case Services, 1990, \#9390-166. 


\section{In Memoriam / 122}

\section{BOOK REVIEWS}

Well over one hundred book reviews, published from 1966 to 2002, appearing in American Historical Review, Business History Review, Business Library Review, Canadian Historical Review, Canadian Journal of History, Canadian Review of American Studies, International Journal, International History Review, Journal of American History, and several other journals. 